Relations industrielles

Industrial Relations

\title{
Labour Standards in Global Value Chains: Disentangling Workers' Voice, Vicarious Voice, Power Relations, and Regulation
}

\section{Les normes du travail dans les chaînes de valeur mondiales : distinguer entre voix du salariat, voix par procuration, relations de pouvoir et règlementation Normas de trabajo en las cadenas globales de valor: desentrañar la voz de los trabajadores, voz vicaria, relaciones de poder y regulación}

\section{Emmanuel Josserand et Sarah Kaine}

Volume 71, numéro 4, automne 2016

URI : https://id.erudit.org/iderudit/1038530ar

DOI : https://doi.org/10.7202/1038530ar

Aller au sommaire du numéro

Éditeur(s)

Département des relations industrielles de l’Université Lava

ISSN

0034-379X (imprimé)

1703-8138 (numérique)

Découvrir la revue

Citer cet article

Josserand, E. \& Kaine, S. (2016). Labour Standards in Global Value Chains: Disentangling Workers' Voice, Vicarious Voice, Power Relations, and Regulation. Relations industrielles / Industrial Relations, 71(4), 741-767. https://doi.org/10.7202/1038530ar
Résumé de l'article

Certains développements théoriques et des études de cas récentes ont commencé à explorer la complexité et les subtilités des nouvelles formes de régulation du travail dans les chaînes de valeur mondiales (CVM). À partir de ces analyses, le présent article cherche à intégrer ce que nous savons déjà dans un cadre cohérent qui puisse guider la pratique et la recherche à l'avenir. Nous y intégrons les connaissances actuelles sur les nouvelles formes de régulation du travail telles les normes sociales privées (NSP) et les accords-cadres internationaux (ACI) - dans un cadre cohérent qui intègre, tout en les démêlant, les déterminants contextuels, processus et mécanismes de régulation, ainsi que les résultats de cette régulation dans les CVM. S'avère particulièrement importante la distinction entre les processus de régulation - tels la voix du salariat (workers' voice en anglais), la voix par procuration (vicarious voice), les campagnes coordonnées au niveau international - et les mécanismes de régulation - tels les NSP et ACI. La littérature existante a tendance à traiter ces diverses formes de régulation sans grande nuance quant à leurs rôles respectifs. Notre cadre identifie deux avenues permettant de passer des processus de régulation aux mécanismes de régulation : le pouvoir des travailleurs et le pouvoir des consommateurs. Il établit également des connexions claires entre concepts, liens de causalité sous-jacents et effets modérateurs.

Nous nous intéressons plus particulièrement à l'impact des structures des chaînes de valeur, des connexions entre voix du salariat et voix par procuration, sur les résultats de la régulation. En ce qui ce qui a trait aux structures des chaînes de valeur, nous examinons le couplage des opérations, la sensibilité des participants à l'intérieur de ces chaînes au risque à la réputation, ce qui procure une influence (drive en anglais) à l'intérieur de ces chaînes de valeurs. Nous ajoutons la dimension significative de « l'influence interne » aux termes déjà convenus du sens de l'influence, cela afin de mieux pouvoir saisir les divergences internes possibles pouvant conduire les gestionnaires principaux dans les multinationales à mettre en place divers types d'incitatifs pour leurs fournisseurs afin de satisfaire aux normes du travail. De plus, nous introduisons le concept de voix par procuration (vicarious voice en anglais), que nous définissons comme une situation dans laquelle le moyen traditionnel qu'est la voix du salariat - tel le syndicalisme local ou l'activisme syndical en tant qu'agent de représentation des travailleurs - se voit remplacé par des acteurs qui n'ont pas de lien de proximité avec les travailleurs. La " voix par procuration " peut s'exprimer par le consumérisme éthique, les groupes de pression sociale, ou les fédérations syndicales internationales.
Tous droits réservés (C Département des relations industrielles de l’Université Laval, 2016
Ce document est protégé par la loi sur le droit d'auteur. L’utilisation des services d'Érudit (y compris la reproduction) est assujettie à sa politique d'utilisation que vous pouvez consulter en ligne.

https://apropos.erudit.org/fr/usagers/politique-dutilisation/ 


\section{Labour Standards in Global Value Chains: Disentangling Workers' Voice, Vicarious Voice, Power Relations, and Regulation}

\section{Emmanuel Josserand and Sarah Kaine*}

Recent research has started to explore the complexity, limitations, and potential of the regulation of labour standards in global value chains (GVCs). Nevertheless, we still lack a framework integrating the contextual determinants, processes, regulatory mechanisms, and outcomes of the regulation of labour standards in GVCs. This paper identifies the key processes in play as workers' voice, vicarious voice, international campaigning, and multi-scalar industrial action and shows how such processes lead to particular forms of labour regulation in GVCs. Two pathways are identified that include context variables and processes and lead to the implementation of regulatory mechanisms: the consumer power pathway and the labour power pathway. We then describe and analyze the factors that determine the shift from implementation to actual outcomes thereby contributing to a better understanding of the issue in theory and practice.

KEYWORDS: labour standards, voice, global value chains, regulation, drive.

\section{Introduction}

Theoretical developments and case studies have started to explore the complexity and intricacies of new forms of regulation of labour in GVCs. The time has now come to integrate what we know into a coherent framework that can guide practice and future research. The purpose of this paper is to establish such a framework, disentangling and connecting the contextual determinants, processes, regulatory mechanisms, and outcomes of the regulation of labour standards in GVCs.

The past 30 years of globalization have seen the influence of multinational corporations (MNCs) extend through the proliferation of complex production

Emmanuel Josserand, Professor, UTS Business School, University of Technology Sydney, Australia (emmanuel. josserand@uts.edu.au).

Sarah Kaine, Associate Professor, UTS Business School, University of Technology Sydney, Australia (Sarah. Kaine@uts.edu.au).

Acknowledgment: We would like to thank the three anonymous reviewers of this paper who provided very useful comments and triggered the reflection that led to our final framework, and Chris F. Wright for helpful comments on a previous version. 
networks spanning national boundaries (O'Rourke, 2003; Robinson and Rainbird, 2011). Employers have reorganized the structure of work, exploiting opportunities for labour cost reduction. Given the increasing complexity of GVC operations, the best efforts of traditional labour regulation are now being "outpaced by changes in the global economy" (O'Rourke, 2003: 2).

Non-traditional forms of regulation such as International Framework Agreements (IFAs) with MNCs, Private Social Standards (PSSs), international campaigns, and multi-scalar industrial action offer an alternative to the traditional tripartite model (Davies et al., 2011; Donaghey et al., 2014; Kaine, 2014). PSSs can range from generic principles in the form of codes of conduct to tight certification standards and can be industry-led and/or involve multi-stakeholders, including unions, businesses, NGOs, and government agencies (ILO, 2016). IFAs are agreements signed between international trade union federations and certain MNCs in order to promote the application of agreed labour standards by the MNCs concerned and, often, their supply chains. These new forms of regulation emerged following unsuccessful efforts to link labour standards with trade regulation in the 1960s and 1970s (Riisgaard and Hammer, 2011). They often leverage transnational institutional-led multi-stakeholder norms such as those defined by the International Labour Organization (ILO), guidelines from the Organization for Economic Cooperation and Development, or the United Nations (UN) Global Compact (Donaghey et al., 2014).

Despite these developments, recent studies show a deterioration in labour rights (Levi et al., 2013), freedom of association, and collective bargaining (Marx et al., 2015). This is because in many cases neither labour nor consumer power are sufficient to trigger the emergence of a governance structure that would compensate for the failure of traditional regulation (Donaghey et al.,2014). Consequently, non-traditional regulation constitutes a "sparse patchwork of global regulations," with many workers not being protected (Koch-Baumgarten and Kryst, 2015). Hence, while recent research has started to explore the potential of the non-traditional regulation of labour standards in the GVC, it has also revealed its complexity and limitations (Alford, 2016), exemplified by the lack of progress on global labour standards.

\section{An integrative framework}

Our framework integrates research on non-traditional forms of regulation of labour standards in GVCs.

\section{Literature review method}

Our framework is based on a systematic review of journal articles in social sciences and business with an initial focus on labour standards in GVCs. Our 
first search included articles that combined two sets of keywords: those relating to labour standards (i.e. 'labour standards', 'social standards', 'work', 'voice', 'regulation', etc.) and those relating to GVCs (i.e. 'global value chain', 'global supply chain', 'global value networks', etc.). We supplemented the literature review with books quoted in the first set of references. We used this first corpus of references to carve out key relevant concepts that were integrated into a first version of our theoretical contribution.

This first conceptualization and feedback from peers led us to conduct more specific searches to refine some key aspects of the framework. Key areas of investigation included ethical consumerism, social advocacy, coupling, drive, PSSs and IFAs. We included all sources relating to concepts that were highly specific to our topic such as PSSs and IFAs. For reasons of relevance and space, more general concepts such as ethical consumerism, coupling or drive meant our referencing was limited to publications seminal to the corresponding concept.

We also included key illustrations from extant research that helped flesh out our model. We focus mainly on the Asia-Pacific area, with Asia being the concentrated site of much of the global production of low-cost goods (United Nations, 2013).

\section{Integrating extant literature}

We used Dunlop (1958) as a broad heuristic to organize our framework, distinguishing between contextual determinants, parties, processes, regulatory mechanisms, and outcomes. While we do not derive our framework model from Dunlop's theory and are cognisant of its limitations (Hameed, 1982; Kelly, 2012; Roche, 1986), we do acknowledge its heuristic value (Muller-Jentsch, 2004) in ordering our framework components. In particular, the processes leading to regulation (for instance, voice or campaigns) and the regulatory mechanisms (such as PSSs and IFAs) are often conflated; differentiating these provides a clearer view of how labour regulation happens and also allows us to posit a series of relationships that can guide further exploratory and explanatory research.

Figure 1 presents the resulting framework and the following sections provide a detailed explanation of the variables and the connections between them. We structure the presentation below by distinguishing two pathways leading to the implementation of regulation mechanisms: the customer power pathway and the labour power pathway. Each pathway includes context variables and processes. The two pathways can lead to the establishment of regulation mechanisms (i.e. PSSs or IFAs) that can ultimately lead to outcomes in terms of labour standards. The relationships between elements of the pathway are noted in Figure 1 and referred to in brackets in the relevant sections of the text. 


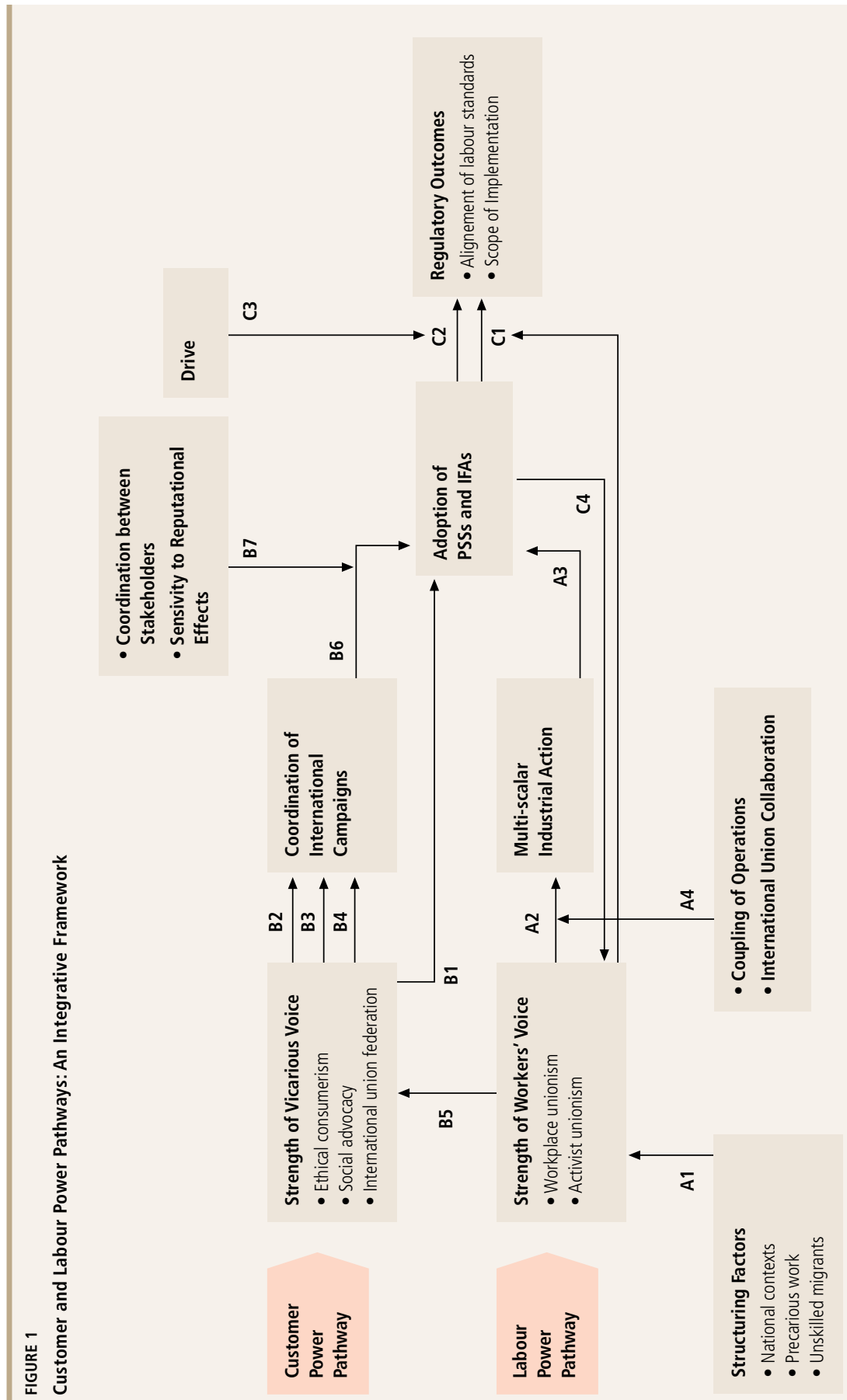




\section{The labour power pathway}

In this section, we present the pathway through which labour power impacts labour standards along GVCs.

\section{Strength of workers' voice}

Workers' voice is a process that includes any means through which workers express discontent with their working conditions and engage in processes to effect change (see Wilkinson et al., 2014). Workplace-based unionism and activist unionism and the associative power on which they are based still remain central to coordinating industrial action intended to lead to the better regulation of labour standards in GVCs.

\section{Workplace unionism}

The two main channels for voice-the unionized 'collective voice' and nonunion employee representation (NER) —are threatened by the fragmentation of GVCs (Riisgaard and Hammer, 2011: 174). Unions face difficulties in maintaining traditional workplace-based voice for workers as a result of the disintegration of the direct employment relationship in favour of outsourcing (Kaine, 2014). However, unions often remain the main channel for voice in GVCs. Because it involves workers' voice at the workplace level (Thelen, 2001), NER does not provide adequate possibilities to channel workers' voice across international supply networks (Davies et al., 2011). Consequently, workplace organizations and local union activity remain important channels for workers' voice in the supply chain and play a key role in monitoring and establishing labour standards in GVCs at the local level (Davies et al., 2011; Riisgaard and Hammer, 2011).

\section{Activist unionism}

However, in some contexts, such as non-democratic or transitioning countries, unions are not necessarily the presumptive channel through which to exercise associative labour power and voice. Instead, dissatisfied workers engage in workplace protests, informal strikes, and short-stoppages (Clarke and Pringle, 2009; Meardi, 2007; Shin, 2010). For instance, Chan and Ngai's study of the rise of the working class in South China details that spontaneous strike incidents rose from 10, 000 to 87, 000 in the period 1993-2005 (2009: 288).

These channels of voice are emerging outside of unions. Workplace leaders increasingly prefer to take an informal role to avoid victimization (Clarke and Pringle, 2009). These spontaneous, informal, and often illegal actions by workers demonstrate 'voice' in spite of state-constructed 'silence,' in situations where state regulation plays against the expression of workers' voice, including the persecution and jailing of workers and their representatives (Chen, 2007). 


\section{Factors structuring workers' voice and silence}

Limiting our consideration of worker dissatisfaction to the observable 'voicing' of concerns obscures the phenomenon of 'silence' (Donaghey et al., 2011). Furthermore, 'silence' or 'voice' are often choices not made freely by workers (Donaghey et al., 2011). It is thus important to explore the factors that structure voice or silence in GVCs.

\section{National contexts}

Many employers operate in contexts that differ from the democratic Western environment that is classically used to frame the concept of voice (Meardi, 2007). For example, in developing countries, micro-studies show that labour law is often disregarded, mainly because of weak law-enforcement mechanisms (McCann, 2008). The question of the political regime and the level of democracy associated with it is key to the avenues open to workers to raise their concerns.

Communist countries pose a particular challenge to any attempt to neatly categorize union voice, especially China, where unions have the dilemma of being both an instrument of the state and (at least notionally) the representatives of workers (Chan and Hui, 2012). This duality is generally resolved in practice in favour of the state. Consequently, Clarke and Pringle (2009) note that: "From the point of view of the international trade union community, the continued subordination of the Chinese and Vietnamese trade unions to the ruling Communist Party disqualifies them from being considered as bona fide trade unions" (87).

The structuring of voice or silence is not problematic in non-democratic contexts alone. Shin (2010) notes the impact of a neo-liberal stance in South Korea, which summarizes the broader challenge for organized labour: "As neo-liberal globalisation by the democratically elected government proceeded, workers' rights were curtailed and threatened" (227).

There is thus a broad range of political circumstances that impose national constraints on workers' voice (Menendez and Lucio, 2014) [see A1 in Figure 1].

\section{Precarious work and workers}

Neo-liberal economic reform produces labour market conditions conducive to the growth of low-quality, precarious jobs, in which workers are ill-equipped to voice concerns. The ILO reports: "With limited stability, earnings and protection, precarious and informal jobs leave workers and their families highly vulnerable, especially in situations of economic, social or environmental crisis" (ILO, 2013: 2). Instances such as the Foxconn suicides in Chinese factories in 2010, which was a case underpinned by the recruitment of a significant student population that fell outside of regulatory protection (Ngai and Chan, 2012), highlight the urgency for change. 
The fact that precarious work intersects with other forms of vulnerability and exclusion, based on age, gender, race, ethnicity, citizenship, and religion, makes it difficult for groups to respond to workplace challenges in a unified way (Sarikakis, 2012) and contributing to the silencing of workers [see A1 in Figure 1].

\section{Unskilled migrant labour}

The existence of unskilled, sometimes illegal, migrant labour further limits workers' voice. The flexible, low-cost nature of unskilled migrant labour, coupled with its reputation for compliance, reliability, and retention, has informed its mass entry into GVCs (Anderson, 2010). Workers alive to the threat of deportation are driven to take any work opportunities, whatever the risks (Ahmad, 2008). In China's Guangdong province alone, home to 26 million migrant workers, $60 \%$ have no contract (Raworth and Kidder, 2009: 177) and most migrant workers in China are unskilled (Chan, 2013). Migrant workers are exposed to specific working conditions depending on their origin. In Thailand, the predicament of immigrant Burmese workers, who roughly comprise $80 \%$ of Thailand's migrant workers, is far worse than that of their Laotian and Cambodian counterparts (Mon, 2010).

Unions have been unable to offer a suitable channel of voice for such workers, especially since a flux of migrant workers creates cleavages in the workforce that complicates the action of labour movements (Shin, 2010). Unskilled migrant workers are thus less likely than other categories to be offered a channel for voice [see A1 in Figure 1].

\section{From voice to multi-scalar industrial action}

Multi-scalar industrial action is characterized by activity cutting across numerous levels and locations in a given GVC, ranging from the workplace to the transnational, and is dependent on the leveraging of structural labour power. This is the "power that results simply from the location of workers in the economic system" (Wright, 2000: 962), in particular when labour can affect other parts of the GVC and have sufficient knowledge of the GVC to do so (Donaghey et al., 2014). Such action could include strikes targeting local companies or solidarity strike action by international unions and the lobbying of governments and MNCs by national unions and global union federations (GUFs). These actions may be intended to effect change at one level, but also have an impact at other levels of GVCs. Riisgaard and Hammer's (2011) exploration of the banana GVC demonstrates how the activities of strong local and regional unions may be the basis for a GUF to relay local workers' voice in order to achieve an IFA.

Multi-scalar action requires the capability to coordinate industrial action internationally. It is facilitated by well-developed international union affiliations 
between local, national, and global federations (Kaine, 2014). Less formal activist unionism does not have the benefit of this connection. While such activism can have a local impact and favours the alignment of labour standards with local workers' needs, the global impact on GVCs is likely to be limited. Wildcat strikes by Wal-Mart workers in China are illustrative of this. These workers engaged in industrial action without the sanction of the existing state-sponsored union and, while they were in contact with unions from other countries, their exclusion from formal bargaining or international union structures has limited their impact (Yang, 2016).

There is emerging evidence that strong workers' voice expressed through the channel of workplace unionism is likely to be conducive to multi-scalar industrial action (Reineke and Donaghey, 2015) [A2 in Figure 1], although it would not be the case for activist unionism (see below for how this form of workers' voice can impact the customer pathway). Such multi-scalar industrial action in turn can lead to the adoption of regulation mechanisms such as PSSs and IFAs [A3 in Figure 1].

\section{Coupling of operations}

The relationship between workplace unionism and multi-scalar industrial action in GVCs is moderated by the coupling of operations and international union coordination. We define the coupling of operations as resulting from a combination of time pressure and the fragmentation of production along the supply chain, where strong coupling is associated with high time pressure and low fragmentation.

In GVCs, structural power is potentially derived from workers' capacity to disrupt the 'flow' between links in the chain (Donaghey et al., 2014). Indeed, some GVCs are characterized by management and production practices such as 'just-in-time' delivery, lean retailing, and the maintenance of small inventories, and these practices may render production networks susceptible to disruption at multiple points. In such cases, workers and their representatives can attempt to unravel the linkages along the chain (Riisgaard and Hammer, 2011), conducting multi-scalar action that exploits the weak points, such as logistical choke points (Coe and Hess, 2013; Weil, 2006).

While connected to structural power, such action is dependent on workers' ability to gain associative power resulting "from the formation of collective organizations of workers" (Wright, 2000: 962). Multi-scalar action can occur only if it brings together, in a timely manner, forces operating at different levels and in different locations in a GVC. Fragmentation of production into a complex network of subcontracting renders the expression of voice through workplace unionism and its transposition into industrial action more difficult (Kaine, 2014). The less 
fragmented the supply chain, the more workers and their representatives are likely to gain associative power leading to industrial action.

Strongly coupled global production networks provide new opportunities for effective industrial action that will moderate the impact of voice in the form of workplace unionism on multi-scalar industrial action [see A4 in Figure 1].

\section{International union collaboration}

In GVCs, the connection of unions across levels and locations is also crucial if they are to gain associative power. Donaghey et al. (2014) indicate: "High associative power depends on the coexistence of three factors: the relationships between supplier-firm unions and lead-firm unions, the degree of unity among unions, and the ability of unions across a supply chain to coordinate solidaristic actions" (238). Such connection can play an important role in establishing multiscalar strategies and can lead to coordinated industrial action, which is a condition of their actual impact on the creation of IFAs and PSSs (Davies et al., 2011). Such international collaborations are not without their complications (Kaine, 2014). For instance, de Neve (2008) studies how the hierarchical structure, a lack of international orientation, and a low level of education and command of English makes it difficult for union leaders in Tiruppur India to maintain their action in face of the globalization of supply networks and a multicultural workforce. In the case they report, only one unionist managed to establish a connection with international organizations, and the leverage obtained was not sufficient to improve the situation for workers. Linguistic, cultural, and political differences can thus undermine the potential of multi-scale associative power.

International union collaboration will thus moderate the impact of workers' voice in the form of workplace unionism on multi-scalar industrial action [see A4 in Figure 1].

\section{The customer power pathway}

In this section, we present the pathways through which customer power impacts labour standards along GVCs. We introduce the concept of 'vicarious voice,' where workers' voice is substituted by that of actors who, unlike local unions or activist unionism, do not have a close representative link with workers.

\section{Strength of vicarious voice}

Vicarious voice is composed of ethical consumerism, social advocacy, and international union federations. The strength of vicarious voice is also connected to the strength of workers' voice, but indirectly so. 


\section{Ethical consumerism}

Donaghey et al. (2014) study customer power in the context of GVCs and with reference to the voice/exit distinction established by Hirschman (1970). Voice, in Hirschman's model, refers mainly to the criticism from 'within' by a customer or a member of an organization who cannot or does not wish to exit (for instance, for a captive or loyal customer). These considerations do not map fully onto the main trend in consumerism that can leverage customer power in the supply chain, namely that of ethical consumerism.

In ethical consumerism, while captive and loyal customers exist, exit has become the channel of choice to express dissatisfaction. This can take the form of temporary or enduring boycotts, or that of buycotts, where customers exit their purchasing relationship with a brand to favour another supplier with stronger ethical credentials (Schmelzer, 2010). The two forms of exit, boycott or buycott, are to be considered primarily as a way to register support for a cause rather than merely exerting economic power (Barnett et al., 2005) and are primarily a way for ethical consumers to voice their concerns.

It is clear that bo/uycotting sends a market signal to the targeted brands, which needs then to be interpreted (Carrier, 2008). The precision of current marketing techniques ensures that the reasons for such changes in customer behaviours are known to major MNCs. Indeed, brand managers measure not only exit, but also a continuum of behaviours and attitudes that include satisfaction, dissatisfaction, propensity to exit and loyalty; this guides them in how they design products to the 'best' attributes, including ethical positioning. Voice is fully integrated in this approach through qualitative interviews and focus groups, surveys, brand communities, and so on. It is not surprising that ethical consumerism exerts a strong influence on sourcing and marketing strategies (Berliner et al., 2015), meaning that ethical consumers can directly influence the adoption of new GVC regulation mechanisms [see B1 in Figure 1,] while also being leveraged into specific campaigns (Barnett et al., 2005) [and see B2].

\section{Social advocacy}

Consumers can expand their role to become more involved in 'customeroriented activism' (Barnett et al., 2005). While this may seem like a questionable distinction to make, it is an important one, since customer-oriented activism paves the way for more committed activities that constitute a basis for social advocacy (Barnett et al., 2005). Such activities may be individual, such as giving or raising money, or signing a petition, or collective, such as participating in campaigns or strikes (Pattie et al., 2003).

Social activism organizations "embed consumer-oriented activism in wider programs of mobilisation, activism, lobbying and campaigning, enrolling ordinary 
people in active political engagement" (Barnett et al., 2005: 45). Ethical consumers can then join forces with other social activists, often combining consumerism with political activism (Barnett et al., 2005). Donaghey et al. (2014) highlight the key role of "hard-hitting social advocacy organisations"(239) in campaigning in favour of the adoption of new forms of labour standard regulation mechanisms [see B3 in Figure 1].

\section{International union federations}

International union federations also play a key role in initiating labour standard campaigns. Unions have started to consider a variety of regulatory opportunities beyond the bounds of traditional employment configurations (Arup et al., 2006; Johnstone et al., 2012), in particular in the context of fragmented supply chains (Wright, 2016). More specifically, unions are using relationships with other civil society organizations to leverage commercial pressures and organizational reputations within both public and private supply chains (Bair and Palpacuer, 2012) The best known example is the long-running Justice for Janitors Campaign in the US where the Service Employees International Union both exposed building owners to public embarrassment if sub-standard labour conditions were found in that owners cleaning supply chain and worked with unionized employers to improve compliance with minimum labour standards (Kaine, 2014). International unions thus participate in or initiate joint campaigns with other stakeholders (Riisgaard and Hammer, 2011) [see B4 in Figure 1].

\section{Workers' voice}

One of the issues associated with vicarious voice is that it represents the actual needs of workers only indirectly. Vicarious voice drives an ethical agenda in which initiatives "are driven by what Western NGOs push for, what large companies consider feasible, and what consultants and accountants seek to provide. [...] the resulting practices and discourse restrict change and marginalise alternative approaches developed by Southern stakeholders" (Bendell, 2005: 362). It may well be that many campaigns, because of a lack of exercise of workers' voice, are manifestations of 'cultural imperialism' (Donaghey et al., 2014).

Micro studies have begun to document the indirect connection between workers' voice and vicarious voice. Berliner et al. (2015) show how Honduran workers brought information about their illegal treatment to the attention of social activism groups that then campaigned for their cause. In the same vein, the Foxconn scandal about labour standards in Apple factories started with striking workers and was then relayed by various groups and the media (Berliner et al., 2015). While some imperialism is in play, workers' voice often generates informa- 
tion (Berliner et al., 2015) that is then amplified (Donaghey et al., 2014) by other stakeholders in the form of vicarious voice [see B5 in Figure 1].

\section{Coordination of international campaigns}

Campaigns leveraging consumer power can link NGOs, unions, and other civil society organizations (Anner et al., 2013); such organizations have long used advocacy campaigns in relation to high-profile global buyers and their suppliers (Barrientos et al., 2010) in an attempt to address the imbalances of power in GVCs (Bair and Palpacuer, 2012; O'Rourke, 2003). Fair trade campaigns and activist networks (Bartley and Child, 2011; Den Hond and De Bakker, 2007; Den Hond et al., 2014; Wright, 2012) seek to guide consumer choice and to deprive unethical businesses of patronage.

Coordinated international campaigns can lead to an alignment of consumer interests with those of workers and "when this happens, it changes the incentives and beliefs of brands, providing a potential source of leverage to raise labour standards" (Berliner et al., 2015: 39). This leads many brands to adopt some form of PSS (Berliner et al., 2015), and such campaigns are instrumental in the adoption of IFAs (Riisgaard and Hammer, 2011) [see B6 in Figure 1].

The impact of such campaigns depends on the coordination between stakeholders and firms' sensitivity to reputational effects.

\section{Coordination between stakeholders}

The effect of international campaigns rests on a precarious alignment of interest between multiple stakeholders (Berliner et al., 2015; Locke, 2013). Cooperation between NGOs and international unions can be problematic and their objectives are not always aligned (Reineke and Donaghey, 2015; Senghaas-Knobloch, 2004).

Coordination between stakeholders is crucial since they supplement each other. Ethical consumerism is key to providing a market signal to corporations, which contribute to campaign legitimacy (Barnett et al., 2005). Furthermore, activist organizations and unions can also exert joint institutional pressure by lobbying key stakeholders, such as institutional buyers or governments, possibly leading to a shift in supply policy for whole systems of provisioning (Barnett et al., 2005) or even sanctions or market closures from importing states (Berliner et al., 2015).

Disparate groups of stakeholders are thus unlikely to produce a sufficient effect to counterbalance the power of MNCs in global supply networks (Locke, 2013). This implies that the level of coordination between stakeholders is likely to moderate the impact of international campaigns on the adoption of PSSs and IFAs [see B7 in Figure 1]. 


\section{Firms' sensitivity to reputational effects}

The foremost aim of international campaigns is to create a negative reputation effect. They are successful in this when they have "modified the beliefs of global brand executives about acceptable actions and increased their incentives to support workers' rights" (Berliner et al., 2015: 166). Not all MNCs will be equally susceptible to the negative impact of reputational effects. Ethical consumerism is sometimes impeded by economic or cultural factors (Schmelzer, 2010) or if customers are more attached to a specific 'flashy' product than to labour standards (Berliner et al., 2015: 39). Furthermore, the threat may be only marginal, as subgroups of consumers have different ethical values (Barnett et al., 2005; Berliner et al., 2015). Finally, ethical consumerism mainly concerns Western consumers; firms operating in other markets might be less sensitive to manifestations of vicarious voice (Donaghey et al., 2014).

Another key factor is the importance of branding for the targeted firm(s). For those MNCs that have increasingly outsourced production activities to focus on branding (Locke, 2013), their brand represents a valuable asset (Berliner et al., 2015). Consequently, branded actors in global supply chains are the key target of international campaigns (Riisgaard and Hammer, 2011). Reputational effects do not only impact brands; they also affect institutional customers and investors (Berliner et al., 2015). Institutional customers may be less sensitive to brands, but could be sensitive to a negative reputation regarding labour practices (Walters et al., 2016), and "the threat of losing multiple institutional purchasers may be a cause for concern" (Berliner et al., 2015: 39). In the same vein, institutional investors are increasingly integrating ethical criteria into their strategies, and poor labour practices in the GVCs of a firm can impede access to financial resources.

In sum, MNCs' sensitivity to reputational risk will vary between firms, product categories, and geographic areas, and such variation will moderate the connection between coordinated international campaigns and the adoption of PSSs or IFAs [see B7 in Figure 1].

\section{From new regulation mechanisms to improved labour standards}

IFAs and PSSs should theoretically result in outcomes that combine broad implementation along the supply chain and the alignment of labour standards with the needs of the workers. Neither of these aspects can be taken for granted, and they are moderated by the drive of leading firms in the GVC and the capability of IFAs and PSSs to foster further the expression of local workers' voice. 


\section{Outcomes of new forms of regulation}

\section{Alignment of labour standards with workers' needs}

While unions are sometimes associated with PSSs, local workers' voice is characteristically either absent or included only symbolically (Coe and Hess, 2013; Raj-Reichert, 2013). In a study of a private standard regarding health and safety in five production sites for HP in Penang, Malaysia, Raj-Reichert (2013) shows the absence of workers' involvement in the process. Even in the case of PSSs in which unions are involved, or in the case of IFAs, the connection with workers is distant.

This distance can result in a lack of alignment with workers' needs if their voice is not directly included in the process. The ethical concerns that shape what is included in the standards are primarily those that resonate with Western consumers and may not align with workers' needs (Carrier, 2008). This can be problematic, since Western consumers do not necessarily have sufficient knowledge to assess the consequences of their choices in full when they operate in a different value system to that of workers (Carrier, 2008). This results in a situation where alignment between customers' and workers' needs may occur in some market segments, but not so much in others. New regulation mechanisms such as PSSs and IFAs thus help meet workers' needs [C1 in Figure 1], but the degree to which they do so will vary from one market segment to another (see below).

\section{Scope of implementation}

One of the promises of IFAs and PSSs is broad implementation. While IFAs apply to all the subsidiaries of a MNC and their suppliers, PSSs can extend to full sectors of activity and the associated supply chains. The actual scope of the implementation of IFAs and PSSs can vary markedly between specific schemes, or even within a specific scheme.

Several limitations can impede implementation: a lack of constraining frameworks, non-amenable national legal cultures, local workplace cultures (Van Tulder et al., 2009; Niforou, 2014), or management attitudes (Riisgaard, 2005). Company audits sometimes also fail to produce timely or lasting results (Berliner et al., 2015; Locke, 2013) and may be subject to falsification (Raj-Reichert, 2013). Implementation along the supply chain can sometimes be difficult, with outsourcing and labour contracting challenging the implementation of IFAs (Riisgaard and Hammer, 2011) and PSSs (Coe and Hess, 2013). In some situations, knowing where the product is manufactured can be difficult to ascertain due to continual relocation of production (Riisgaard and Hammer, 2011), especially in deep supply chains with highly mobile SMEs at the bottom (Berliner et al., 2015). Altogether, while IFAs and PSSs should lead to the broad implementation of labour standards along the supply chain [see C2 in Figure 1], implementation will vary from one scheme to the next. 


\section{Factors influencing alignment and implementation}

\section{Drive of lead firm(s)}

Drive has been defined as the power of some key firms-whether they are retailers (in buyer-driven chains) or industrial enterprises (in producer-driven ones) - over the rest of the supply chain (Gereffi, 1994). Gereffi et al. (2005) provide a typology of value-chain governance, with five possible governance types corresponding with a level of drive. These forms are (by growing level of drive): the market, the modular, the relational, the captive, and the hierarchy. According to Gereffi et al. (2005), compared to market governance, modular governance is characterized by a strong ability to codify complex transactions, thus limiting asset specificity (Bair, 2008). Relational governance differs from modular in the sense that codification capability is low. Captive governance is characterized by a strong power asymmetry because of the low capabilities of the supply base. Gereffi et al. (2005) also stress the importance of taking into account powerful actors operating at different levels of the supply chain, since several actors may be in a position to set the parameters of its operations. This approach captures more precisely the power of the lead firm(s) than the distinction between producer- and buyer-driven supply chains (Gereffi, 1994) that was used by previous research on labour standards in the supply chain (Donaghey et al., 2014; Riisgaard and Hammer, 2011).

Taking into account the type of value chain governance operating at a level in the chain allows for a finer understanding of the power of a specific actor or group of actors over the other levels of the supply chain. It thus supplements Gereffi's (1994) holistic approach to drive (Bair, 2008). It allows for an understanding of external drive along the supply chain as possibly resulting from the power of several actors or groups of actors, situated at different levels along the chain. This means that GVCs can be both buyer- and producer-driven; the extent of the power of an actor or group of actors at one level over other levels up and down the chain depends on the nature of the governance of their ties with the actors positioned at these other levels.

External drive is important to generate social regulation since driving firms are more likely to have the power to shape the rules (Riisgaard and Hammer, 2011), including "how financial, material and human resources are allocated and flow within a chain" (Gereffi, 1994: 96). This means that firms with such power can influence the scope of implementation of IFAs and PSSs by using their power to favour implementation through the organization of their network.

This approach is focused on 'external drive.' We add to this the dimension of internal drive, referring to the capability of such firms to apply consistent incentives internally to the managers of their different departments. Contradictory internal 
key performance indicators and strategies (Locke, 2013) within firms may send conflicting signals to other participants in the GVC. Often, the social incentives sent by lead firms are contradicted by cost imperatives that apply to internal departments and impact subcontractors. This can lead internal managers to shift their sourcing in search of savings and to favour lower costs over ethical concerns (Locke, 2013), providing a conflicted and inadequate incentive to suppliers, who then worsen rather than improve labour standards (Berliner et al., 2015; Locke, 2013; Riisgaard, 2009). Internal drive is thus essential if the firm is to exert its power over a supplier in a way that will increase the scope of implementation of regulative mechanisms.

The exercise of such power is not necessarily coercive; it can be more collaborative. Locke (2013) describes how a collaborative approach, where the lead firm and its auditors work jointly with suppliers to learn how labour standards can be improved, can bring about differences in implementation between two otherwise similar factories subcontracting for the same brand. In terms of labour standards, this means that firms with drive can influence the scope of implementation of IFAs and PSSs by using their power coercively or collaboratively [see C3 in Figure 1].

\section{Embedding local workers' voice}

Embedding local workers' voice in new regulation mechanisms is key for both alignment and implementation. Research underlines a paradox in worker representation, namely that IFAs and PSSs are effective locally only in cases where unions are already strong (Riisgaard and Hammer, 2011). It appears that workplace unionism is essential to implementation and ongoing compliance. Indeed, Riisgaard and Hammer (2011) note that the relocation of production to non-union areas was a challenge to the implementation of IFAs, while unions were essential in the local leveraging of PSSs. Micro-studies about the implementation of IFAs show that their connection with local workers is highly dependent on the strength of local labour unions (Hammer, 2005). The capability of local unions to "ride the standards" included in PSSs is critical (Riisgaard, 2009: 335). Similarly, the capability of local unions to access the workplace, disseminate information, and monitor implementation explains the differences in local implementation regarding IFAs (Riisgaard, 2005). In the absence of local workers' voice, new regulatory mechanisms are likely to suffer in terms of both alignment and implementation.

IFAs and PSSs can also result in the development of new opportunities for workers' voice, for example, in the form of local union development, thus favouring local deployment and alignment with workers' needs. However, there is a variation in the degree to which PSSs and IFAs facilitate the emergence of local channels for workers' voice. While some PSSs have no such facilitating mechanisms, others 
promote capacity building for unions and local civil society organizations, leading to "the inclusion of the equally important countervailing voices of existing unions and local labour support organizations" (Rodriguez-Garavito, 2005: 228). Unions are actively seeking to include freedom of association as a constitutive provision of PSSs (Riisgaard and Hammer, 2011). Additionally, education programs and procedures for individual workers to file complaints can be a useful inclusion (Rodriguez-Garavito, 2005). IFAs usually include such provisions and consequently contribute to establishing organizing rights (Hammer, 2005) suggesting that IFAs "can lead to constructive dialogue as well as create space for local level organizing" (Riisgaard, 2005: 730).

In terms of labour standards, this means that firms with drive can influence the scope of implementation of IFAs and PSSs by using their power-coercively or collaboratively - to favor implementation by both managers within the firms and the upstream and downstream organizations of their network [see C3 in Figure 1].

\section{Discussion}

In this paper, we have integrated existing knowledge on new forms of regulation of labour standards into a coherent framework that integrates and disentangles the contextual determinants, processes, regulatory mechanisms, and outcomes of that regulation in GVCs. Of special significance is the distinction between regulatory processes-vicarious voice, workers' voice, and coordinated international campaigns-and regulatory mechanisms-IFAs and PSSs. Extant literature tends to deal with existing forms of regulation without much clarity on their respective roles. Our framework also contributes by identifying two pathways from regulatory processes to regulatory mechanisms: the labour power and the customer power pathways. Our framework also establishes clear connections between concepts, underlining links of causality and moderating effects.

We discuss below the implications of our framework for understanding the impact of two key factors on labour standards: the structure of the supply chain and the connections between workers' and vicarious voice.

\section{Drive, reputation effect, and coupling in GVCs}

Extant literature has summarized the argument about the impact of the power characteristic of GVCs on labour standards by arguing that labour power is more likely to threaten production in production-driven chains, while customer power is more likely to threaten consumption in buyer-driven ones (Donaghey et al., 2014; Riisgaard and Hammer, 2011). While this argument was legitimate in specific exploratory cases and important to initiate consideration of the issues, it fails to distinguish the impact of drive from that of two other factors clearly 
delineated in our framework: the coupling of operations and firms' sensitivity to reputational effects. This distinction is important because whereas a buyerdriven supply chain can operate in a context where there is no brand sensitivity, a production-driven supply chain, such as exists in the automotive industry, can be very sensitive to brand and thus reputational effects. Our framework refines our understanding of the impact of the different structural characteristics of GVCs on labour standards in three ways.

First, the coupling of operations is recognized in the framework as moderating the impact of workplace organization on industrial action. We argue that coupling, and not the fact that the supply chain is production-driven, is the key structural factor relating to a GVC that will moderate labour's ability to leverage its power without customers' support (or other forms of vicarious voice).

Second, we clarify the role of firms' sensitivity to reputational risk as moderating the effect of coordinated international campaigns on the adoption of PSSs or IFAs. Former research confused the impact of reputational effect-mainly a negative impact on brands-and drive (Riisgaard and Hammer, 2011), even though they impact very different aspects of GVCs, as presented in our framework.

Third, we introduce important aspects that bring new perspectives to the concept of drive. We use Gereffi et al.'s (2005) typology of the types of network connecting the members of a supply chain, from market to hierarchy; we also stress the importance of taking into account the fact that several actors, positioned at different levels of the supply chain, can have the power of drive. This captures more precisely the power of the lead firm(s) than the distinction between producer- and buyer-driven supply chains. Another important distinction is that which exists between external and internal drive, which accounts for the possible internal discrepancies leading managers in MNCs to apply mixed incentives to their suppliers. We also introduce the possibility of collaborative power, which may be a more efficient way to trigger change than the mere coercive version that has led many initiatives to fail. Finally, we clarify the precise impact of drive, namely that it moderates the impact of IFAs and PSSs adoption on the actual scope of implementation.

\section{Varieties of voice along GVCs}

Scant attention has been paid to the role of workers' voice in the implementation of regulatory mechanisms such as IFAs and PSSs. Our framework highlights the circumstances in which workers' voice may lead to mechanisms that regulate labour standards in GVCs. A key contribution we make is defining 'vicarious voice,' which captures a situation where workers' voice is substituted by that of actors, including ethical consumers, social advocates, and international union federations. 
We also analyze the relationship between workers' voice and vicarious voice and its components. Our framework shows how voice progresses along the supply chain and into processes connecting the local and the global and leveraging labour and customer power. We show how workers' voice can be leveraged at a global level both in customer power and in labour power pathways. We also clarify its role as one of the antecedents of vicarious voice.

We show how the components of vicarious voice interact with other variables in the model, clarifying how customers' voice manifests through ethical consumerism. Of special importance is the decision to move beyond the classic distinction of exit and voice (Hirschman, 1970) that has been used so far in reference to customer power (Donaghey et al., 2014) to show the intricacies between exit and boycott as the main form of voice and to contrast this with more politically engaged social advocacy activities.

\section{Research avenues}

Our framework provides clear causal links between the contextual determinants, regulatory processes, regulatory mechanisms, and labour standards outcomes in GVCs. It can thus directly be operationalized into testable hypotheses. As our objective was to provide a holistic description of the key concepts and the links between them, we chose not to formulate detailed, testable propositions. However, future research should endeavour to test the different links presented here using data from different GVCs. While all relationships between concepts in our framework are grounded in extant literature, some areas would benefit from further empirical exploration.

First, while we know that in some cases GVC coupling can be exploited for industrial action (Gereffi and Lee, 2016), we still have very little evidence on how this happens in practice and only limited insight into the success factors for such actions. Similarly, further research is needed on the success factors for international campaigns. Extant research has only just begun to explore the diversity of regulatory mechanisms and the relationship between their specific characteristics, and the scope and alignment of their implementation.

Second, the question of drive is certainly one that requires further exploration and testing. We need to investigate further how complex arrangements combining both the internal and the external drive of actors at different levels of GVCs, and mediated by different types of networks, can be approached to impact the scope of implementation of new forms of GVC regulation favourably. Such research, based on our framework, will help us fully embrace the complexities of GVC structures and the impact of these on labour standards.

Finally, customers' voice relayed by international campaigns is becoming the 'resistance of choice' for efforts within GVCs. With the dearth of channels to 
nurture workers' voice, the capacity for these to develop into multi-scalar action is limited, relegating workers' voice to its vicarious counterparts in the context of GVCs. It is also imperative and timely that research should be tackling the question of voice, silence, and vicarious voice in GVCs, a challenge that our theoretical analysis aspires to help frame.

\section{References}

Ahmad, Ali Nobil. (2008). "Dead Men Working: Time and Space in London's ('Illegal') Migrant Economy." Work, Employment and Society, 22 (2), 301-318.

Alford, Matthew. (2016). "Trans-Scalar Embeddedness and Governance Deficits in Global Production Networks: Crisis in South African Fruit." Geoforum, 75, 52-63.

Anderson, Bridget. (2010). "Mobilizing Migrants, Making Citizens: Migrant Domestic Workers as Political Agents." Ethnic and Racial Studies, 33 (1), 60-74.

Anner, Mark, Jennifer Bair, and Jeremy Blasi. (2013) "Toward Joint Liability in Global Supply Chains: Addressing the Root Causes of Labor Violations in International Subcontracting Networks." Comparative Labor Law and Policy Journal, 35 (1), 1-43.

Arup, Christopher, Peter Gahan, John Howe, Richard Johnstone, Richard Mitchell, and Anthony O'Donnell. (2006). Labour Law and Labour Market Regulation: Essays on the Construction, Constitution and Regulation of Labour Markets and Work Relationships. Sydney: Federation Press.

Bair, Jennifer and Florence Palpacuer. (2012). "From Varieties of Capitalism to Varieties of Activism: The Antisweatshopmovement in Comparative Perspective." Social Problems, 59 (4), 522-543.

Bair, Jennifer. (2008). "Analysing Economic Organization: Embedded Networks and Global Chains Compared." Economy and Society, 37 (3), August, 339-364.

Barnett, Clive, Nick Clarke, Paul Cloke, and Alice Malpass. (2005). "The Political Ethics of Consumerism." Consumer Policy Review, 15 (2), 45-51.

Barrientos, Stephanie, Gary Gereffi, and Arianna Rossi. (2010). Economic and Social Upgrading in Global Production Networks: Developing a Framework for Analysis. Capturing the Gains Working Paper. Retrieved from: http://www.capturingthegains.org/publications/ workingpapers/index.htm,_(March, 2010).

Bartley, Tim and Curtis Child. (2011). "Movements, Markets and Fields: The Effects of Sweatshop Campaigns on U.S. Firms, 1993-2000." Social Forces, 90 (2), 425-451.

Bendell, Jem. (2005). "In Whose Name? The Accountability of Corporate Social Responsibility." Development in Practice, 15 (3-4), 362-374.

Berliner, Daniel, Anne R. Greenleaf, Milli Lake, Margaret Levi, and Jennifer Noveck. (2015). Labor Standards in International Supply Chains: Aligning Rights and Incentives. Cheltenham: Edward Elgar Publishing.

Carrier, James G. (2008). "Think Locally, Act Globally: The Political Economy of Ethical Consumption." Research in Economic Anthropology, 28, 31-51.

Chan, Chris King-chi. (2013). "Community-Based Organizations for Migrant Workers' Rights: The Emergence of Labour NGOs in China." Community Development Journal, 48 (1), 6-22. 
Chan, Chris King-Chi, and Elaine Sio-ieng Hui. (2012). "The Dynamics and Dilemma of Workplace Trade Union Reform in China: The Case of the Honda Workers' Strike." Journal of Industrial Relations, 54, 653-668.

Chan, Chris King-Chi, and Ngai, Pun. (2009). "The Making of a New Working Class? A Study of Collective Actions of Migrant Workers in South China." The China Quarterly, 198 (1), 287-303.

Chen, Feng. (2007). "Individual Rights and Collective Rights: Labor's Predicament in China." Communist and Post-Communist Studies, 40 (1), 59-79.

Clarke, Simon and Tim Pringle. (2009). "Can Party-Led Trade Unions Represent Their Members?" Post-Communist Economies, 21, 85-101.

Coe, Neil M. and Martin Hess. (2013). "Global Production Networks, Labour and Development." Geoform, 44, 4-9.

Davies, Steve, Nikolaus Hammer, Glynne Williams, Rajeswari Raman, Clair Siobhan Ruppert, and Lyudmyla Volynets. (2011). "Labour Standards and Capacity in Global Subcontracting Chains: Evidence from a Construction MNC." Industrial Relations, 42 (2), 124-138.

De Neve, Geert. (2008). "Global Garment Chains, Local Labour Activism: New Challenges to Trade Union and NGO Activism in the Tiruppur Garment Cluster, South India." Research in Economic Anthropology, 28, 213-240.

Den Hond, Frank and Frank G. A. de Bakker. (2007). "Ideologically Motivated Activism: How Activist Groups Influence Corporate Social Change Activities." Academy of Management Review, 32 (3), 901-924.

Den Hond, Frank, Sjoerd Stolwijk, and Jeroen Merk. (2014). "A Strategic Interaction Analysis of an Urgent Appeal System and its Outcome for Garment Workers." Mobilization, 19 (1), 83-111.

Donaghey, Jimmy, Juliane Reinecke, Christina Niforou, and Benn Lawson. (2014). "From Employment Relations to Consumption Relations: Balancing Labor Governance in Global Supply Chains." Human Resource Management, 53 (2), 229-252.

Donaghey, Jimmy, Niall Cullinane, Tony Dundon, and Adrian Wilkinson. (2011). "Reconceptualising Employee Silence: Problems and Prognosis." Work, Employment and Society, 25 (1), 51-67.

Dunlop, John Thomas (1958). Industrial Relations Systems. New York: Henry Holt Co.

Gereffi, Gary and Joonkoo Lee (2016). "Economic and Social Upgrading in Global Value Chains and Industrial Clusters: Why Governance Matters." Journal of Business Ethics, 133 (1), 25-38.

Gereffi, Gary, John Humphrey, and Timothy Sturgeon (2005). "The Governance of Global Value Chains." Review of International Political Economy, 12 (1), 78-104.

Gereffi, Gary. (1994). "The Organization of Buyer-Driven Global Commodity Chains: How U.S. Retailers Shape Overseas Production Networks." In G. Gereffi and M. Korzeniewicz (eds.), Commodity Chains and Global Capitalism. Westport, CT: Praeger, 95-122.

Hameed, Syed M. A. (1982). "A Critique of Industrial Relations Theory. Industrial Relations, 37 (1), 15-31.

Hammer, Nikolaus. (2005). "International Framework Agreements: Global Industrial Relations Between Rights and Bargaining." Transfer, 11 (4), 511-530.

Hirschman, Albert O. (1970). Exit, Voice, Loyalty: Response to Decline in Firms, Organizations and States. Cambridge, MA: Harvard University Press. 
International Labour Organization. (2016). Decent Work in Global Supply Chains. Report IV, International Labour Conference, ILO Geneva.

International Labour Organization. (2013). Asia-Pacific Labour Market Update. Retrieved from: http://www.ilo.org/wcmsp5/groups/public/---asia/---ro-bangkok/---ilo-islamabad/ documents/publication/wcms_232657.pdf, (January 4th, 2015)

International Organization for Migration. (2014). Global Migration Trends December 2014. Retrieved from: http://missingmigrants.iom.int/sites/default/files/Global-migration-trends_ December-2014_final.pdf, (January 14th, 2015 ).

Johnstone, Richard, Shae McCrystal, Igor Nossar, Michael Rawling, and Joellen Riley. (2012). Beyond Employment: The Legal Regulation of Work Relationships. Sydney: The Federation Press.

Kaine, Sarah. (2014). "Union Voice." In A. Wilkinson, J. Donaghey, T. Dundon, and R. Freeman (eds.) Handbook of Employee Voice. Cheltenham: Edward Elgar, 170-187.

Kelly, John. (2012). Rethinking Industrial Relations: Mobilisation, Collectivism and Long Waves. London: Routledge.

Koch-Baumgarten S. amd M. Kryst. (2015). "Trade Unions and Collective Bargaining Power in Global Labour Governance." In A. Marx, J. Wouters, G. Rayp, and L. Beke (eds.), Global Governance of Labour Rights. Cheltenham: Edward Elgar Publishing, 150-169.

Levi, Margaret, Christopher Adolph, Daniel Berliner, Aaron Erlich, Anne Greenleaf, Milli Lake, and Jennifer Noveck. (2013). Aligning Rights and Interests: Why, When and How to Uphold Labour Standards. Background Paper for the World Development Report.

Locke, Richard M. (2013). The Promise and Limits of Private Power: Promoting Labour Standards in a Global Economy. New York: Cambridge University Press.

Marx, A., J. Wouters, L. Beke, and G. Rayp. (2015). "The Protection of International Labour Rights: A Longitudinal Analysis of the Protection of the Rights of Freedom of Association and Collective Bargaining over 30 Years in 73 Countries." In A. Marx, J. Wouters, G. Rayp, and L. Beke (eds.), Global Governance of Labour Rights. Cheltenham: Edward Elgar Publishing, $13-41$.

McCann, Deidre. (2008). "The Regulation of Working Conditions in Asia and the Pacific: Flexibility, Fragmentation and Workers Rights." In F. Eyraud and S. Lee (eds.), Globalization, Flexibilization and Working Conditions in Asia and the Pacific, Geneva: International Labour Office.

Meardi, Guglielmo. (2007). "More Voice After Exit? Unstable Industrial Relations in Europe." Industrial Relations, 38 (6), 503-523.

Menenddez, Maria Gonzalez and Miguel Martinez Lucio. (2014). "Voice Across Borders: Comparing and Explaining the Dynamics of Participation in a Context of Change." In J. Donaghey, T. Dundon, and A. Wilkinson, (eds.), Handbook of Employee Voice. Cheltenham: Edward Elgar, 381-397.

Mon, M. (2010). "Burmese Labour Migration into Thailand Governance of Migration and Labour Rights." Journal of the Asia Pacific Economy, 15 (1), 33-44.

Muller-Jentsch, Walther. (2004). "Theoretical Approaches to Industrial Relations." In Bruce Kaufman (ed.), Theoretical Perspectives on Work and the Employment Relationship. Ithaca: Cornell University Press, 1-40.

Ngai, Pun and Chris King-Chi Chan. (2012). "Global Capital, The State And Chinese Workers: The Foxconn Experience." Modern China, 38 (4), 383-410. 
Niforou, Christina. (2014). "International Framewwork Agreements and Industrial Relations Governance." Economic and Industrial Democracy, 35 (2), 367-386.

O'Rourke, Dara. (2003). "Outsourcing Regulation: Analyzing Nongovernmental Systems of Labour Standards and Monitoring." Policy Studies Journal, 31 (1), 1-29.

Pattie, Charles, Patrick Seyd, and Paul Whiteley. (2003) "Citizenship and Civic Engagement: Attitudes and Behaviour in Britain", Political Affairs, 51, 443-468.

Raj-Reichart, Gale. (2013). "Safeguarding Labour in Distant Factories: Health and Safety Governance in an Electronics Global Production Network." Geoforum, 44, 23-31.

Raworth, Kate and Kidder Thalia. (2009). "Mimicking the 'Lean' in Golden Value Chains: It's the Workers Who Get Leaned On." Frontiers of Commodity Chain Research. J. Bair, ed. Stanford: Stanford University Press, 165-189.

Reinecke, Juliane and Jimmy Donaghey. (2015). "After Rana Plaza: Building Coalitional Power for Labour Rights between Unions and (Consumption-Based) Social Movement Organisations." Organization, 22 (5), 720-740.

Riisgaard, Lone. (2005). "International Framework Agreements: A New Model for Securing Workers Rights?" Industrial Relations: A Journal of Economy and Society, 44 (4), 707-737.

Riisgaard, Lone. (2009). "Global Value Chains, Labour Organization and Private Social Standards: Lessons from East African Cut Flower Industries." World Development, 37 (2), 326-340.

Riisgaard, Lone and Nikolaus Hammer. (2011). "Prospects for Labour in Global Value Chains: Labour Standards in the Cut Flower and Banana Industries." British Journal of Industrial Relations, 49 (1), 168-190.

Robinson, Pamela K. and Helen H. Rainbird. (2011). Beyond the Organisation and the Nation State...and the Employment Relationship, Same as Ever Was? Global Value Chains and the Challenges for Industrial Relations Research. Paper presented at BJIR $50^{\text {th }}$ Anniversary Conference: Across Boundaries: An Interdisciplinary Conference on the Global Challenges Facing Workers and Employment Research, London.

Roche, William K. (1986). "Systems Analysis and Industrial Relations: Double Paradox in the Development of American and British Industrial Relations." Economic and Industrial Democracy, 7 (1), 3-28.

Rodríguez-Garavito, César A. (2005). "Global Governance and Labour Rights: Codes of Conduct and Anti-Sweatshop Struggles in Global Apparel Factories in Mexico and Guatemala." Politics and Society, 33 (2), 203-333.

Sarikakis, Katharine. (2012). "Access Denied: The Anatomy of Silence, Immobilization and the Gendered Migrant." Ethnic and Racial Studies, 35 (5), 800-816.

Schmelzer, Matthias. (2010). "Marketing Morals, Moralizing Markets: Assessing the Effectiveness of Fair Trade as a Form of Boycott." Management and Organizational History, 5 (2), 221-250.

Senghaas-Knobloch, Eva. (2004). Global Economic Structures and Global Governance in Labour Regulation Policy. Artec-Paper No. 113, 1-23.

Shin, Kwang-Yeong. (2010). "Globalisation and the Working Class in South Korea: Contestation, Fragmentation and Renewal." Journal of Contemporary Asia, 40 (2), 211-229.

Thelen, Kathleen. (2001). "Varieties of Labour Politics in the Developed Democracies." In P. Hall and D. Soskice, (eds.), Varieties of Capitalism: The Institutional Foundations of Comparative Advantage. Oxford: Oxford University Press, 71-103. 
United Nations. 2013. "Global Value Chains and Development: Investment and Value Added Trade in the Global Economy, A Prelimary Analysis". United Nations Conference on Trade and Development (UNCTAD). New York: United Nations.

Van Tulder, Rob, Jeroen Van Wijk, and Ans Kolk. (2009). "From Chain Liability to Chain Responsibility." Journal of Business Ethics, 85 (2), 399-412.

Walters, David, Philip James, Helen Sampson, Syamantak Bhattacharya, Conghua Xue, and Emma Wadsworth. (2016). "Supply Chain Leverage and Regulating Health and Safety Management in Shipping." Relations industrielles/Industrial Relations, 71 (1), 33-56.

Weil, David. (2006). Lean Retailing and Supply Chain Restructuring: Implications for Private and Public Governance. Paper prepared for Observing Trade: Revealing International Trade Networks. Princeton: Princeton University.

Wilkinson, Adrian, Tony Dundon, Jimmy Donaghey, and Richard B. Freeman. (2014). "Employee Voice; Charting New Terrain." In Adrian Wilkinson, Jimmy Donaghey, Tony Dundon, and Richard B Freeman (eds.), Handbook of Research on Employee Voice. Cheltenham: Edward Elgar, 3-16.

Wright, Chris F. (2016) "Leveraging Reputational Risk: Sustainable Sourcing Campaigns for Improving Labour Standards in Production Networks." Journal of Business Ethics, 137 (1), 195-210.

Wright, E. O. (2000). "Working-Class Power, Capitalist-Class Interests, and Class Compromise." American Journal of Sociology, 105 (4), 957-1002.

Yang, Y. (2016). "Walmart Workers Launch Wildcat Strikes across China." Financial Times, July $7^{\text {th }}$. Retrieved from: https://www.ft.com/content/d1dd7376-4408-11e6-9b66-0712b3873ae1 (accessed 1 August 2016).

\section{SUMMARY}

\section{Labour Standards in Global Value Chains:}

Disentangling Workers' Voice, Vicarious Voice, Power Relations, and Regulation

Theoretical developments and case studies have started to explore the complexity and intricacies of new forms of labour regulation in Global Value Chains (GVCs). This paper builds on these to integrate what we know into a coherent framework that can guide practice and future research. We bring together existing knowledge on new forms of labour standards regulation-such as Private Social Standards (PSSs) and International Framework Agreements (IFAs) -into a framework that integrates and disentangles the contextual determinants, processes, regulatory mechanisms, and outcomes of such regulation in GVCs. Of special significance is the distinction between regulatory processes-vicarious voice, workers' voice, coordinated international campaigns-, and regulatory mechanisms-IFAs and PSSs. Extant literature tends to deal with existing forms of regulation without much clarity on their respective roles. Our framework identifies two pathways from regulatory processes to regulatory mechanisms: the labour power and the 
customer power pathways. Our framework also establishes clear connections between concepts, underlining links of causality and moderating effects.

We explore the impact of value chain structure, and specifically, the connections between workers' and vicarious voice, on regulatory outcomes. With regard to the structure of supply chains, we examine the coupling of operations and the sensitivity of value chain participants to reputational risk and drive within value chains. We add the significant dimension of 'internal drive' to existing understandings of drive to capture the possible internal discrepancies leading managers in multinational companies (MNCs) to apply mixed incentives to their suppliers to comply with labour standards. Additionally, we introduce the concept of 'vicarious voice', which we define as a situation where workers' voice is substituted by that of actors who, unlike local unions or activist unionism, do not have a close representative link with workers. Vicarious voice may be composed of ethical consumerism, social advocacy, and international union federations.

KEYWORDS: labour standards, voice, global value chains, regulation, drive.

\section{RÉSUMÉ}

\section{Les normes du travail dans les chaînes de valeur mondiales: distinguer entre voix du salariat, voix par procuration, relations de pouvoir et règlementation}

Certains développements théoriques et des études de cas récentes ont commencé à explorer la complexité et les subtilités des nouvelles formes de régulation du travail dans les chaînes de valeur mondiales (CVM). À partir de ces analyses, le présent article cherche à intégrer ce que nous savons déjà dans un cadre cohérent qui puisse guider la pratique et la recherche à l'avenir. Nous y intégrons les connaissances actuelles sur les nouvelles formes de régulation du travail - telles les normes sociales privées (NSP) et les accords-cadres internationaux (ACl) - dans un cadre cohérent qui intègre, tout en les démêlant, les déterminants contextuels, processus et mécanismes de régulation, ainsi que les résultats de cette régulation dans les CVM. S'avère particulièrement importante la distinction entre les processus de régulation - tels la voix du salariat (workers' voice en anglais), la voix par procuration (vicarious voice), les campagnes coordonnées au niveau international - et les mécanismes de régulation - tels les NSP et ACI. La littérature existante a tendance à traiter ces diverses formes de régulation sans grande nuance quant à leurs rôles respectifs. Notre cadre identifie deux avenues permettant de passer des processus de régulation aux mécanismes de régulation : le pouvoir des travailleurs et le pouvoir des consommateurs. Il établit également des connexions claires entre concepts, liens de causalité sous-jacents et effets modérateurs.

Nous nous intéressons plus particulièrement à l'impact des structures des chaînes de valeur, des connexions entre voix du salariat et voix par procuration, sur les résultats de la régulation. En ce qui ce qui a trait aux structures des chaînes de valeur, nous 
examinons le couplage des opérations, la sensibilité des participants à l'intérieur de ces chaînes au risque à la réputation, ce qui procure une influence (drive en anglais) à l'intérieur de ces chaînes de valeurs. Nous ajoutons la dimension significative de "I'influence interne " aux termes déjà convenus du sens de l'influence, cela afin de mieux pouvoir saisir les divergences internes possibles pouvant conduire les gestionnaires principaux dans les multinationales à mettre en place divers types d'incitatifs pour leurs fournisseurs afin de satisfaire aux normes du travail. De plus, nous introduisons le concept de voix par procuration (vicarious voice en anglais), que nous définissons comme une situation dans laquelle le moyen traditionnel qu'est la voix du salariat - tel le syndicalisme local ou l'activisme syndical en tant qu'agent de représentation des travailleurs - se voit remplacé par des acteurs qui n'ont pas de lien de proximité avec les travailleurs. La " voix par procuration » peut s'exprimer par le consumérisme éthique, les groupes de pression sociale, ou les fédérations syndicales internationales.

MOTS-CLÉS : normes du travail, voix, chaines de valeurs mondiales, règlementation, influence (drive en anglais).

\section{RESUMEN}

\section{Normas de trabajo en las cadenas globales de valor: desentrañar la voz de los trabajadores, voz vicaria, relaciones de poder y regulación}

Los avances teóricos y los estudios de casos han comenzado a explorar la complejidad y las complicaciones de las nuevas formas de regulación del trabajo en las cadenas globales de valor (CGV, Global Value Chains). Este artículo se basa sobre estos avances para integrar esos conocimientos en un modelo coherente que pueda guiar la práctica y las futuras investigaciones. Integramos así el conocimiento existente sobre las nuevas formas de regulación de las normas de trabajo - tal que las Estándares sociales privados(ESPs) y los acuerdos marco internacionales (AMIs) - dentro de un modelo que integra y esclarece los determinantes contextuales, los procesos, los mecanismos de regulación, y los resultados de dicha regulación en las CGVs. Se destaca, de manera especialmente significativa, la distinción entre los procesos de regulación - voz vicaria, voz de los trabajadores, campañas internacionales coordinadas - y los mecanismos de regulación (ESP y AMIs). La vasta literatura tiende a tratar las formas existentes de regulación sin mucha claridad en cuanto a sus roles respectivos. Nuestro modelo identifica dos vías que conducen los procesos de regulación hacia los mecanismos de regulación: la vía del poder laboral y la del poder de los consumidores. Nuestro modelo establece también conexiones claras entre los conceptos, enfatizando los vínculos de causalidad y los efectos moderadores.

Exploramos específicamente el impacto sobre los resultados regulatorios de la estructura de las cadenas de valor, las conexiones entre la voz de los trabajadores y 
la voz vicaria. Con respecto a la estructura de las cadenas de suministro, examinamos el acoplamiento de las operaciones, la sensibilidad de los participantes de las cadenas de valor a arriesgar su reputación y respecto al poder de influencia (drive) ejercido dentro de las cadenas de valor. Agregamos la dimensión significativa de "poder de influencia interna " (internal drive) a la comprensión existente del poder de influencia y capturar así las discrepancias internas posibles que conducen los directivos en las MNCs a aplicar incentivos mixtos a sus proveedores para cumplir con los requisitos de las normas laborales. Además, introducimos el concepto de " voz delegada " que definimos como una situación donde la voz de los trabajadores es substituida por la voz de otros actores quienes, a diferencia de los sindicatos locales o del sindicalismo activista, no tienen vínculos estrechos de representación con los trabajadores. La voz vicaria puede estar compuesta de representantes del consumismo ético, de defensores sociales y de federaciones sindicales internacionales.

PALABRAS CLAVES: Normas laborales, voz, cadenas de valor globales, regulación, poder de influencia (drive). 